\title{
SOUTH AFRICA: POLITICAL LIFE TODAY
}

\section{Vladimir Shubin ${ }^{2}$}

Among the events that took place in South Africa in recent years, three can be named as most important: BRICS summit in Durban (eThekwini ${ }^{3}$ ), the death of Nelson Mandela and the general election.

The Fifth BRICS Summit was held on 26-27 March 2013 in Durban under the motto - "BRICS and Africa: Partnership for Development, Integration and Industrialization", proposed by the leadership of South Africa. Apart from eThekwini Declaration and Plan of Action, it resulted in signing a number of agreements in the presence of the BRICS leaders. The BRICS Business Council was set up within the framework of multilateral co-operation and a declaration on the establishment of the BRICS Think Tank Council was adopted. On South Africa's initiative the Retreat, a dialogue forum on the theme "Unlocking Africa's potential: BRICS and Africa. Cooperation on Infrastructure", was attended by heads of state and government, heads of African continental and regional organizations and their seniors, including the chairperson of the African Union Commission Nkosazana Dlamini-Zuma.

At a time when the BRICS countries are experiencing considerable economic difficulties, there are voices that this association has not lived up to expectations. However, speaking in Ufa at the Seventh BRICS Summit in July 2015 South African President Jacob Zuma was more optimistic. He noted that "Both South Africa and the African continent have benefitted from our economic cooperation with our BRICS partners. South Africa's total trade with BRICS in $201 \mathrm{II}$ was R268 billion and has since grown to $\mathrm{R}_{3} 82$ billion in 20I4, an increase of 70\%. BRICS total trade with Africa

I The article has been written with financial support of the Russian Foundation for Humanities, project I6-07-0038, "South Africa, a strategic partner of Russia".

2 Institute for African Studies, Russian Academy of Sciences, Moscow, Russia. E-mail: vlgs@yandex.ru

3 eThekwini is the name of the metropolitan municipality that now includes the city of Durban. 
doubled since 2007 to US dollar 340 billion in $20 \mathrm{I} 2$ and is projected to reach US dollar 500 billion by 2015 "4.

Like the holding of the BRICS summit in Durban, the world reaction to Nelson Mandela' death and the farewell to him with the participation of leaders of dozens of countries in December 2013 reaffirmed that South Africa holds a special place not only on the continent but also in the on the international arena. It was in Johannesburg at the farewell ceremony when Barak Obama approached Cuban leader Raul Castro and shook his hand, symbolizing the beginning of the normalisation of the bilateral relations.

The third important event, general election took place in May 2014. The African National Congress won a landslide victory, gaining $62.15 \%$ of the vote ${ }^{5}$, only $3.5 \%$ lower than five years earlier. However, it should be borne in mind that less than only $60 \%$ of South African citizens, eligible to vote, used their right, and so the total number of votes received by the ANC was even less than in the first general election 20 years earlier.

The fact that the ANC has the support of a large majority and the opposition had not been able to present a real challenge on the national scale was confirmed, although this general election was the most difficult for it. The ANC, a governing party for over 20 years, acts in an alliance with two other organizations - the Congress of South African Trade Unions (COSATU) and the South African Communist Party (SACP) that themselves do not participate in elections, but their members join parliament and cabinet as the ANC members. However a new striking feature of the political life in South Africa at present is the fact that each of the members of the "tripartite alliance" experiences problems.

Jacob Zuma became the ANC President, when at the party conference in Polokwane in December 2017 he defeated then President Thabo Mbeki, receiving the support of 60\% of the delegates. In May 2009, Zuma confidently took over as President of the Republic of South Africa, and then in December 20I2 at the next ANC conference in Mangaung received even greater support than five years earlier - more than $70 \%$ of the delegates. Yet the second candidate - the then deputy president of the ANC (and of South Africa) Khalema Motlanthe virtually led no campaign either for his election or reelection for his previous post. So, Cyril Ramaphosa occupied

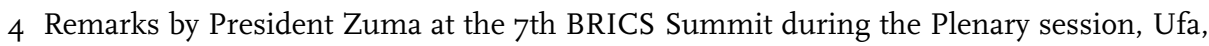
Russia. http://www.thepresidency.gov.za/pebble.asp?relid=20075

5 http://www.elections.org.za/resultsnpezoI4/ 
the second highest post in the ruling party. As Motlanthe, he previously served as secretary general of the National Union of Miners, then secretary general of the ANC, and even was second after Mandela in the list of the party in the elections of I994, although the post of Deputy President of South Africa at the last moment was proposed not to him, but to Thabo Mbeki. After the completion of the work of the Constitutional Assembly, which he chaired, in 1997 he went into business and has achieved, although not immediately, a great success, becoming a billionaire, at least, in South African rands. It should be noted that the two other candidates for the post of ANC Deputy President (and potentially after the next general election due to in 2019 of the country president) - Mosima "Tokyo" Sexwale and Matthews Phosa are also successful businessmen.

The ANC conference delegates clearly manifested concern of a slow pace of social and economic transformation and this has found expression in the adoption of provisions on the "second phase of the transition from apartheid colonialism to a national democratic society", which "will be characterised by decisive action to effect economic transformation and democratic consolidation, critical both to improve the quality of life of all South Africans and to promote nation-building and social cohesion"6. According to Zuma, during that stage, a "radical shift" should have occured toward greater state involvement "needed to play an active role in helping to democratise and deracialise the ownership and control of an economy"7.

The arrival of Jacob Zuma to the highest post in the ruling party, and then in a country considered by many in South Africa as a "Left Turn" or at least "a potential for a Left Turn". But so far there is hardly any basis for such judgments, moreover, during Zuma's second term in office the political situation in the country deteriorated. In its election campaign, the ANC has used two anniversaries - its centenary, celebrated during the whole 20I2, and the twentieth anniversary of the establishment of a democratic system in South Africa in April I994. But in the political lexicon, especially of opponents of the government, two other terms prevailed - Nkandla and Marikana.

In the first case, it was about the erection of several facilities at public expense in Jacob Zuma's private estate in his birthplace, in Nkandla in KwaZulu-Natal. The investigation of this issue took several months, but for some reason, its results were published in a nearly 450-page report of the Public Protector Thuli Madonsela on I9 March 20I4 at the height of

6 Declaration Of the 53rd National Conference of the ANC. http://www.anc.org.za/events. php?t=53rd\%20National\%20Conference\%20-\%20Mangaung

$7 \mathrm{http} / /$ www.miningweekly.com/print-version/go-deeper-than-call-for-nationalisationzuma-urges-anc-delegates-2012-07-06 
the election campaign. It argued that some of them - Visitors' Centre, the cattle kraal, the swimming pool - cannot be justified in terms of the South African National Key Points Act (that covers President's residences).The report suggested that Zuma should "pay a reasonable percentage of the cost of the measures as determined with the assistance of National Treasury" . Naturally, such a report was a "gift" for the opposition on the eve of the election. However, later the minister of police Nathi Nhleko claimed that the report exaggerated costs several times, and that in any case the President was not liable to pay back for "necessary security features" 9 . His position was supported by the ANC majority of members of Parliament, but that was not the end of the story.

The second case was a real tragedy. On August I6, 201234 miners were killed and 78 injured by police bullets near the Marikana platinum mine in South Africa's North Western Province. They participated in a "wildcat" strike demanding a salary increase of three times (!). Under the conditions of tough confrontation in the area ten persons had been killed earlier, including two police officers and two employees of the Lonmin company.

This tragedy has caused a major stir in the country, it was compared with the shooting Africans in Sharpeville on 21 March I960, and police actions were subjected to stiff criticism. However, in this situation, the government did not "sweep the rubbish under the carpet", it established a commission of inquiry, headed by a prominent lawyer, a retired judge of the Supreme Court of Appeal (by the way, white) Ian Farlam, which had the right to question policemen, miners, government officials and employees of the company. Its meetings were public, they were shown on television. Originally, the commission was supposed to work for four months, but its term was extended for more than two years; the final 660-page report ${ }^{\text {to }}$ was handed over to the country's president in April 2015 to be published for some reason much later - in June. The report contains a detailed critical assessment of the actions of Lonmin ${ }^{\text {II }}$, the police, AMCWU, trade-union

8 http://www.publicprotector.org/library\%5Cinvestigation_report\%5C2OI3-I4\%5CFinal\%2O Report\%2019\%20March\%202014\%20.pdf

9 http://www.gov.za/speeches/report-minister-police-parliament-security-upgradesnkandla-private-residence-president-28

Io http://www.thepresidency.gov.za/medialib/downloads/downloads/Full\%20Report\%20 of $\% 2$ othe\%2oMarikana\%2oCommision\%2oof\%2oInquiry.pdf

II Cyril Ramaphosa was a board member and owner of the shares of that company. In the run up to the massacre, he emailed politicians and police urging them to take tougher action against the striking miners, because events around the strike were "plainly dastardly criminal acts and must be characterised as such". Ramaphosa wanted the police "to act in a more pointed way" (http://www.ft.com/cms/s/o/44d49cd4-2I64-IIe4-a958-ooI44feabdco. 
that organized the strike and suggested measures to prevent such tragedies. Not all were pleased with the results of the report, but the investigation of the tragedy demonstrated a democratic nature of the South African state.

The tragedy in Marikana eclipsed a very important event in the economic and political life of South Africa, the publication on the previous day, August I5, 20I2 of the National Development Plan, prepared after two years of work by the National Planning Commission (NDP)) - "Our Future. Make it work. 2030" 2 . This extensive document, which consists of almost 500 pages, proclaims its main goal the elimination of poverty and reduction of inequality and identifies ways to achieve their goals. In particular, the NDP envisaged increase in the number of employees from $\mathrm{I} 3$ million in 2010 to 24 million in 2030 , and the growth of annual average per capita income from 50 thousand rand to 120 thousand rand $^{\mathrm{I3}}$.

The drafting of the project by the NDP Commission was followed by six months of "public consultation to build consensus and refine the plan" ${ }^{\text {I4. }}$. However, talking about the real consensus would be wrong. In particular, COSATU, the largest trade union federation and private sector unions belonging to it were especially critical. The discussion paper prepared by the leadership of COSATU said: "The NDP proposes cosmetic reforms to the economic structure, aimed at best deracialise ownership,

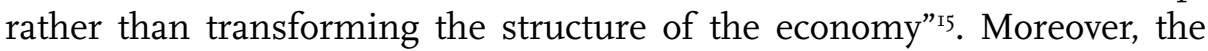
implementation of the plan has been slower than expected, for example, only I. $3 \%$ economic growth was achieved in $2015^{16}$, although the $5.4 \%$ was envisaged in the Plan.

Earlier, the differences in the vision of the future of the country and ways to it appeared on the June 2012 ANC Policy Conference. Although the demands for nationalization of mines were not supported in fear that such steps without compensation would push away investors while spending huge sums of money for compensation would be unrealistic, the proposal for "state intervention" was approved ${ }^{\mathrm{I} 7}$. In particular, a single mining company was to control the state-owned shares in the mining industry, while it was

html\#axzz4AKdRuLUa). The inquiry cleared Ramaphosa of inciting the killing, but victims' families are trying to pursue him through the courts.

I2 http://www.gov.za/issues/national-development-plan-2030

I3 http://www.gov.za/issues/national-development-plan-2030, p. 34 .

I4 Ibid. p. 483.

I5 http://www.cosatu.org.za/docs/discussion/20I3/NDPcritiquesummary.pdf. p.II

I6 http://www.tradingeconomics.com/south-africa/gdp-growth

I7 AFRICAN NATIONAL CONGRESS RECOMMENDATIONS FROM THE 4TH NATIONAL POLICY CONFERENCE JUNE 20I2, p. 35. http://www.anc.org.za/list. php?t=Policy\%2oDocuments. 
suggested that they should be up to $30 \%$ of the industry. Such a company - African Exploration Mining and Finance Corporation had already been established earlier, but initially had a modest goal - to supply coal to power plants belonging to the public sector. And by 2016 the state owned only two mines in coal and diamond mining.

Let us look now at the political spectrum of the South African society. The major opposition party is Democratic Alliance (DA). In general election the party, headed then by Helen Zille, the premier of the Western Cape significantly strengthened its position, not only in that province, but also in the economic center of South Africa - Gauteng. Across the country, the DA received $22.23 \%, 5.5 \%$ more than in 2009 primarily at the expense of smaller parties.

However, immediately after the elections the DA faced an unpleasant situation, its "rising star" Lindiwe Mazibuko, who led its faction in the National Assembly, preferred a master student fellowship in one of the American universities to the parliamentary seat.

Third, to the surprise of many, was the party formed only a few months before the elections, in October 2013 -"Economic Freedom Fighters" (EFF) with $6.35 \%$ of votes. Its "Commander-in- Chief" is Julius Malema, the former head of the ANC Youth League. Initially an ardent supporter of the ANC incumbent President in his conflict with Thabo Mbeki (Malema became famous, or, rather, notorious for his phrase "I will kill for Zuma"), he began criticizing Zuma from the "left", or, more exactly, populist position, advocating the "economic freedom" (hence and the unusual name of the party), and requiring, in particular, the nationalization of the mining industry. ANC leadership resorted to administrative measures; Malema was expelled from the organization and began to create his own one. It should be noted that his way of life is far from "proletarian", the South African Revenue Service wanted him to pay dues totaling the amount of over I8 million rand including interest $\mathrm{t}^{\mathrm{1} 8}$ while the prosecutor's office accused him on 54 counts of money laundering, corruption, racketeering and fraud ${ }^{\mathrm{I} 9}$.

Another new party participated in the elections, "Agang" ("Let us build" in Sesotho and Setswana languages) founded by Mamphela Ramphele, known, above all, as a "partner" of Steve Biko, a prominent opponent of the apartheid regime, who died in 1977 in police custody shortly after his arrest. Surprisingly, just prior to the election it was announced that Ramphele would be a DA candidate for the presidency. A photo of kissing two women

I8 http://www.polity.org.za/article/an-uncompromising-stance-the-dispute-between-sarsand-julius-malema-continues-2016-05-16

I9 http://www.news24.com/SouthAfrica/News/LIVE-Tight-security-ahead-of-Malemascourt-appearance-20150803 
leaders - her and Helen Zille went around the Internet and mass media, but this "same-sex marriage" (in South Africa, they are, by the way, legal) lasted only three days, and "Agang" stood in the election independently. It got two seats in the National Assembly, but, oddly enough, Ramphele refused to take one of them and soon withdrew from politics.

Meanwhile in May 20I5 Helen Zille herself gave way to the new leader of her party, a young African Mmusi Maimane ${ }^{20}$, retaining however the post of premier of the Western Cape. The move was seen not only as an attempt of the DA to get rid of the image as primarily white party, it aimed at winning the majority at the local elections in August 2016 in "Big Five” - five major cities, including Johannesburg and Tshwane (Pretoria). Much less were expectations of the Congress of the People, the party that earlier broke away from the ANC; and it received in 2014 less than ten percent of 2009 votes. Another looser was the Inkatha Freedom Party, led by former "Chief Minister" of KwaZulu bantustan Gatsha Buthelezi, who three decades earlier claimed to be the national leader of Africans.

So, ANC still holds a solid majority in parliament, but there is a growing disappointment with the results of its rule, both in the ranks of the party itself, and especially among its allies. The "radical" leadership of the National Union of Metalworkers (NUMSA), numbering about 350 thousand, not only criticized the ANC government for adopting "a neo-liberal document like the National Development Plan" ${ }^{21}$, but also initiated the adoption by the union conference a decision to refuse the support of the ANC at the elections. Following this, the NUMSA has announced plans to create a broad opposition movement and "a MarxistLeninist revolutionary working class political party"22.

The organizing committee of a new movement, named the United Front was formed in December 20I4. It seems that its founders hoped to repeat the success of the United Democratic Front (UDF), which brought together widespread opposition to the apartheid regime three decades ago. However, the difference between the fronts immediately became obvious: in contrast to the UDF, a new front is being created from the top and so far with little success: its founding conference was postponed several times and its dates are not yet fixed. As to the creation a new party, practically a rival the SACP, the process did not go before the declarations of intent.

It should be noted, however, that the plans of the formation of the

20 Maimane has Master degrees in public administration from University of the Witwatersrand and in theology from Bangor University, Wales, he is also a pastor and elder of the conservative Liberty Church.

2I http://www.fin24.com/Economy/Numsa-gears-up-for-special-congress-20I3IOI8

22 http://www.numsa.org.za/article/numsa-central-committee-statement-2/ 
new structures deepened divergence within the left in South Africa. Some former prominent members of the SACP were involved, in particular Ronnie Kasrils, a former member of the Politburo, who held a number of positions in governments of Mandela and Mbeki, became a member of the UF National Working Committee, and Mazibuko Jara, a former spokesman of the Communist Party, became its National Secretary.

It would be wrong however to speak of a "split" in the SACP, or of a "departure" of a significant number of its members. On the contrary, its numerical strength in recent years rose "in leaps and bounds" to 230 thousand, and majority of them are young ${ }^{23}$. Several dozen members of the SACP are members of parliament, five, including Party General Secretary Blade Nzimande and its Chairperson Senzeni Zokwana, are Ministers and three Deputy Ministers. However, all of them occupy these posts as ANC members, but proposals to participate in the elections independently, and not only in the framework of the Congress, are advanced increasingly often in recent years, particularly in the Young Communist League.

The SACP leadership is facing a dilemma: many communists are critical of the NDP, but as members of the government and officials they had to implement it. For example, the First Deputy General Secretary Jeremy Cronin wrote that "But the NDP is not a ready-made implementation plan, it is more a vision. It consists of some useful insights and recommendations, intriguing but untested proposals, summaries of programmes long under way, and much else. These are sandwiched between an opening section of cringe worthy poetry ('Our leaders' wisdom is ours, because we sense our wisdom in theirs...") and a clumsy attempt to present a social contract theory... From the outset, the SACP has warned against "monumentalising" the NDP - either idolising it or seeking to tear it down like Saddam Hussein's statue in Baghdad. All serious plans need to be relatively open-ended and subject to learning from experience" ${ }^{24}$. However at the same time, according to Cyril Ramaphosa, Cronin, a deputy minister, is alongside him "leading the charge in implementing the programmes that are set out in the National Development Plan"25.

More difficult situation is evolving in the trade union movement. After NUMSA's expulsion from COSATU in November 2015 its leaders seek to attract other unions for the creation of "a new, worker-controlled, democratic, non-racial, non-sexist, independent, financially self-sufficient, internationalist, socialist-orientated and militant union federation". The

23 http://www.iol.co.za/news/politics/sacp-membership-growing---cronin-I88I80o 24 http://www.news24.com/Opinions/Jeremy-Cronin-responds-to-Trevor-Manuels-attackon-the-SACP-201507I9

25 https://www.enca.com/south-africa/government-will-not-turn-away-ndp-ramaphosa. 
"Workers summit" was held on 30 April 2016 and expressed hope that "the founding congress [of such federation] can be convened by the latest in 20I7, possibly earlier" ${ }^{26}$. Thus, the ambitious plans of NUMSA leadership included the establishment of an alternative to all three components of the ANC-led alliance, but up to now they failed.

Such actions were taking place against the background of the worsening economic and political situation in South Africa. One of the most dramatic events was a wave of xenophobia that swept a number of cities in the country in April 20I5 when several people (both foreigners and South Africans) were killed and thousands of citizens of other African countries fled or were deported as illegal migrants.

The reasons for this crisis was the dissatisfaction of many local people, especially Africans, by a low rate of socio-economic transformation, and it was "fuelled" by the speech of so called "king of the Zulus nation" Goodwill Zwelithini, who said that "foreigners must pack their bags and go home". However his defenders claimed that the remarks, made in the Zulu language, "have been misconstrued and only referred to the deportation of illegal immigrants" ${ }^{27}$. ANC and its allies have done much to counter this wave - from demonstrations in defense of migrants to the involvement of the army to help the police. The "Operation Fiela", a campaign to restore order followed in the course of which over 9 o०० arrests have been made and over I5 000 undocumented immigrants repatriated ${ }^{28}$.

Then, in the second half of October 2015 South Africa faced a student unrest caused by the increase of by more than $12 \%$ of tuition fees in a number of universities. Mass demonstrations, accompanied in some cases by the clashes with the police took place near the parliament in Cape Town, near the headquarters of the ANC in Johannesburg and, finally, on 23 October near the Union Buildings, the offices of the President of South Africa in Tshwane. The decision to raise the fees was taken over by the university rectors, who are sometimes paid higher than ministers and even the President, but the blame was deflected onto to the government, and Jacob Zuma was forced to personally declare a zero increase in student fees in the next school year ${ }^{29}$. However the disturbances from time to time still happen, and in a very ugly forms such as setting fire on the of university premises.

26 http://www.numsa.org.za/article/declaration-workers-summit-may-day-rally/

27 http://www.theguardian.com/world/20I5/apr/20/south-africa-xenophobic-violencezulu-king-goodwill-zwelithini

28 http://mg.co.za/article/20I5-09-07-the-numbers-behind-operation-fiela

29 http://www.news24.com/SouthAfrica/News/Zero-increase-in-fees-Zuma-20151023] 
Such was the situation when Jacob Zuma became a target not only for criticism, but for direct calls for his resignation. To a large extend this new wave of vilification is connected with the appearance of one more term in the South African political vocabulary, that is "state capture" $3^{\circ}$, attributed first and foremost to the Gupta family. Three Gupta brothers, Ajay, Atul and Rajesh came to South Africa from India beginning from I993 and established a versatile business, allegedly using their connections with President and his family. Zuma's fourth wive, Bongi Ngema Zuma, worked for the Guptas, one of his sons, Duduzane, was a director in some of the Gupta family companies and President's daughter Duduzile was appointed as a director of Gupta-owned Sahara Computers in 2008, soon after her father was elected as ANC leader, although she has since resigned ${ }^{31}$.

The first major scandal involving them happened in 2013 when a chartered plane from India with the guests for Gupta family wedding was allowed to land at the Waterkloof Air Base near Pretoria, normally reserved for visiting heads of state and diplomatic delegations ${ }^{32}$. More serious developments took place late last year. On December 9 President Zuma suddenly dismissed Finance Minister Nhlanhla Nene, replacing him with well-educated but "unknown backbencher" Des van Rooyen ${ }^{33}$. The next day new minister arrived at National Treasury with his two "advisers" who were identified as "Gupta allies". "Their arrival so shook the Treasury that its Director General threatened to resign and his staff immediately dubbed the event "9/12" - a reference to the US's disastrous "9/II" of 200I"34.

President's decision was detrimental to the country's financial system: rand weakened by two for a USD and R50obn were wiped off the value of South African assets. The outcry in the country was so great that the members of the tripartite alliance distanced themselves from Zuma's decision and in four days President had to reverse his appointment, replacing van Rooyen with Pravin Gordhan, who previously held this post in $2009-2014.35$

30 The efforts of a small number of firms (or such groups as the military, ethnic groups and kleptocratic politicians) to shape the rules of the game to their advantage through illicit, non-transparent provision of private gains to public officials, he noted that examples of such behaviour include the private purchase of legislative votes, executive decrees, court decisions and illicit political party funding.

3I http://www.bbc.com/news/world-africa-225I34Io. Malema “coined" a new term "Zuptas" to refer to their alleged influence on Zuma.

32 Ibid.

33http://www.fin24.com/BizNews/named-van-rooyens-two-gupta-advisors-who-almosthijacked-sa-treasury-20160215

34 Ibid.

35 Ibid. 
There were indications that, just ahead of these developments "somebody (presumably with foresight into the events about to unfold) took a multi-billion rand bet against the currency (technically known as "shorting"). They borrowed rands to purchase dollars and when the rand crashed they sold the dollars back for rands, walking away with several billions in profit" ${ }^{36}$.

Furthermore, Msebizi Jonas, Deputy Finance Minister publicly stated that on the eve of Nene's dismissal the Guptas offered him Minister position ${ }^{37}$. Similar accusations were made by some other officials. Under these circumstances President and his family hurried to distance themselves from the Guptas, in particular his son Dudusane immediately resigned from his post ${ }^{38}$, though Zuma insisted in parliament that none of his cabinet ministers had been appointed by "the Guptas or anybody else" 39 and two months later reiterated that he knew "nothing about the dealings of the Gupta family and whoever" $4^{\circ}$. The scandal was so serious that Gupta brothers preferred to urgently leave South Africa and the ANC National Executive Committee decided to investigate whether President's relationship with the Gupta family has started a process of "capture of the state" ${ }^{\mathrm{I}}$. Finally, on 27 August Guptas announced that they would sell all their shares in South Africa by the end of $20164^{2}$.

Soon time more bad news came for president. The Constitutional Court unanimously decided that the power of the Public Protector to take appropriate remedial action has legal effect and was binding and therefore Zuma had to pay back the money used on his private home in Nkandla, the final figure to be determined by the National Treasury. In rather strong words the Court also held that, by failing to comply with the Public Protector's order, the President failed to "uphold, defend and respect" the Constitution. Besides, it held that the National Assembly's resolution, based on the Minister of Police's findings exonerating the President from liability, was inconsistent with the Constitution and unlawful ${ }^{43}$.

36 http://www.sacp.org.za/main.php?ID=5353\#sthash.kw2c7jC5.dpuf

37 http://mg.co.za/article/20ı6-03-r6-guptas-offered-me-finance-minister-position-mcebisijonas

38 http://www.fin24.com/Economy/breaking-guptas-resign-from-oakbay-20I60408

39 http: / / www.ft.com/cms / s / o/didi 5888 -ec4d-i I 5-bb79-2303682345c8. html\#axzz4AiSzXlLC.

40 http://ewn.co.za/2016/05/I7/Zuma-reiterates-he-never-lied-about-Nkandla

4I http://ewn.co.za/20I6/03/2I/ANC-to-investigate-Zuma-relationship-with-the-Guptafamily

42 AAN7 TV, 27 August 2017.

43 http://www.news24.com/SouthAfrica/News/full-text-constitutional-court-rules-on- 
Then the Gauteng High Court renounced the decision taken by National Prosecution Authority before the 2009 election to drop the criminal case against Zuma and declared that he "should face the charges as outlined in the indictment" that is 783 counts of alleged corruption, fraud and racketeering. Moreover, it ruled that this decision to abandon the charges had been misguided and that Mokotedi Mpshe, then chief prosecutor, had acted under pressure ${ }^{44}$. To avoid reopening of the case the NPA decided to appeal against the Court's decision and so to "send a clear message that political interference in the work of the NPA would not be tolerated"45.Zuma has joined the NPA to appeal the decision; however they were dismissed ${ }^{46}$.

Under these circumstances the demands for Zuma's resignation could be heard from various political corners. The most "radical", as usually, is EEF that called also for dissolution of parliament and new general election ${ }^{47}$. The direct calls to Zuma to resign (or "to take a proper step") were made by Ahmed Kathrada, a Rivonia trialist ${ }^{48}$, by other ANC veterans ${ }^{49}$, by a group of religious leaders ${ }^{50} \ldots$.. Others, like a group of seniour commanders and commissars of the Umkhonto we Sizwe (ANC People's Army) called on the leadership of the ANC "to urgently convene a special National Conference to assess these challenges and chart a way forward to restore the prestige of our glorious movement and the State" 5 .

However, there were other moods as well. The ANC Youth League even proposed to nominate Zuma as president of the Congress for a third term ${ }^{52}$ and his supporters raised their hands with three fingers curved, signaling support for this initiative. As distinct from the South Africa's constitution, the charter of the ANC do not prescribe limitations on the

nkandla-public-protector-2016033I

44 http://www.telegraph.co.uk/news/20I6/04/29/south-african-court-clears-way-for-jacobzuma-to-face-783-crimin/

45 http://www.bdlive.co.za/national/20I6/05/24/appeal-looks-beyond-zuma-case-says-npa $46 \mathrm{http}: / /$ allafrica.com/stories/20I6062500I4.html

47 http://www.southcoastnews.co.za/eff-calls-for-dissolution-of-parliament/.

48 http://www.news24.com/SouthAfrica/News/ahmed-kathrada-asks-zuma-to-resign-readit-in-full-20I60402

49 http://www.ft.com/cms/s/o/cd6274a8-fcob-Ire5-b5f5-o7odca6doaod. html\#axzz4AmtYiek3

$50 \mathrm{http} / / /$ ewn.co.za/20I6/04/o8/Religious-leaders-tell-the-ANC-Zuma-mu-st-go

5I http://www.polity.org.za/article/anc-commanders-memorandum-from-seniorcommanders-and-commissars-of-the-former-military-wing-of-the-anc-umkhonto-wesizwe-2016-03-24 52 http://citizen.co.za/768228/third-term-for-zuma-shot-down-in-flames/ 
term of office of its supreme leader, but it is worth recalling that similar actions by Thabo Mbeki ended in his resignation. In the October 2015 Zuma at ANC General Council clearly stated that he would never participate in elections for a third term as leader of the party, even if the ANC "begged him" 53 , however earlier he pledged not to stand for the second term as country's president but then changed his mind.

Holding his position, Zuma also expressed the opinion that it is not the time to address the issue of succession in the ANC. Nevertheless, this topic is being hotly debated in South Africa. New South African President to be elected by parliament after the next elections, which will take place in 20I9, but since it is expected that the ANC will keep a majority in parliament, the name of the future head of state will be practically determined two years earlier, at the next ANC conference that will elect new president of the party.

So far, there are two most likely candidates for that post (and therefore later for the highest public office): Cyril Ramaphosa and Zuma's former wife Nkosazana Dlamini-Zuma. There are conflicting opinions about Ramaphosa's political views. When he was secretary general of the National Union of Miners, he openly advocated socialism, but later, after leaving public office, has become a very successful businessman. His answer to the question whether he is still a socialist was rather peculiar: "Yes, I am. But I have coined my own phrase, which in many ways describes what I am. I am a socialist but I operate in a capitalistic world. I am therefore a capitalist with a socialist instinct." ${ }^{54}$

Ramaphosa's chances, as of Zuma's deputy on both his posts looks high, however strong sentiments are expressed in South Africa in favor of the election a women as the supreme leader. This was recently openly declared by the president of the ANC Women's League, Minister of Social Development Bathabile Dlamini5s, and Nkosazana Dlamini-Zuma is the most frequently mentioned name in this respect. A strong and influential person, she previously held several ministerial posts and in 2012 was elected the Chairperson of the African Union Commission in Addis Ababa. Her term in the office finally ends in January 2017 and her decision not to seek the second term was considered by many as a sign of her preference for an important post at home.

All in all the ANC leadership are aware of the problems arising in the ranks of the organization in a difficult socio-economic situation. "Corruption, [perceived or real], factionalism, political ill-discipline and the

53 http://ewn.co.za/20I5/Io/ır/Zuma-rules-out-3rd-term-even-if-ANC-begged-him.

54 http://mg.co.za/article/20I5-o9-Io-is-ramaphosa-still-a-shoo-in.

55 http://mg.co.za/article/20I5-09-2I-political-ill-discipline-a-danger-to-anc-unity-mantashe 
use of money to subvert internal democratic processes were identified as posing a very serious and real danger to the unity and cohesion of the ANC," said Gwede Mantashe, Secretary General of the Congress (and member of the SACP CC) $)^{5}$. Not surprising, therefore, that its membership has fallen from one million in 2012 , when the party turned 100 , to 769.000 by October $2015^{57}$.

The seriousness of problems was underlined by SACP second deputy general Solly Mapaila, in whose words members of the ANC and its alliance partners who speak out against state capture may be risking their lives, and various party officials - himself included - had recently received death threats ${ }^{5}$.

Growing tensions in the South African political life raise questions about the possibility of influence of external forces on the evolving situation. This is not limited by idle "conspiracy theories"; it looks like more serious information appeared on this subject, for example, Baleka Mbete, ANC National Chairperson and Speaker of the National Assembly, said: "Those people (EFF) are not working with people of this country alone; they are pawns in a bigger scheme of things where some western governments are involved"59.

Moreover, South Africa's State Security Agency (SSA) in March 2015 confirmed that it was investigating allegations of collaboration with the CIA of a number of prominent persons, aforementioned Thuli Madonsela, Julius Malema, Lindiwe Mazibuko and Joseph Matundzhvi, the head of the AMCU trade union that organized a strike in Marikana ${ }^{60}$.In October 2015 the SSA said the investigation was at an "advanced stage"6r, but its results have never been reported.

In any case, there is no doubt that the position of the South African ruling party on international issues (it is expressed in ANC documents more "openly" than in the official government statements) cannot but be a concern of certain forces in the West. For example, the Discussion Document prepared for the October 20I5 meeting of the ANC National General Council said: "Russia has not been spared the wrath of US-led Western imperialism

56 Ibid.

57 http://www.iol.co.za/news/politics/pics-anc-4th-national-general-council-I.I927774\#. VizUWCspqzk

58 http://www.polity.org.za/article/you-risk-your-life-if-you-speak-out-against-state-capturesacps-mapaila-2016-06-03

59 http://mg.co.za/article/20I5-02-I4-mbete-eff-are-pawns-of-the-west-who-want-to-controlsa

6o http://mg.co.za/article/20I5-03-05-ssa-investigating-political-leaders

6I http://sa-monitor.com/top-Io-bogus-anc-conspiracy-theories-bdlive-25-may-2oI6/ 
... The war taking place in Ukraine is not about Ukraine. It intended target is Russia. ... Russia's neighbors are being mobilized to adopt a hostile posture against Moscow, and enticed to join the European Union and NATO"62.

The recent confirmation of the CIA involvement into arrest of Nelson Mandela in 1962 was widely commented in South Africa and the statement made on this occasion by Zizi Kodwa, ANC spokesperson, speaks volumes. "We always knew there was always collaboration between some western countries and the apartheid regime... We have recently observed that there are efforts to undermine the democratically elected ANC government," he said. "They never stopped operating here. It is still happening now - the CIA is still collaborating with those who want regime change"63.

Nevertheless Pravin Gordhan was right to underline the primarily domestic origin of the problems the ANC is facing: "We need to revolutionise our own politics. If we ourselves don't change the way we do things, no one will. I don't think we are under attack by outside people. We give them the fuel to attack us" ${ }^{64}$.

Indeed, whatever is the interference from outside, so called "coloured revolutions", be it in North Africa, Central Asia or South America can succeed only when the local conditions are conducive to them.

In this respect the position expressed by Dr Bonginkosi "Blade" Nzimande, the SACP General Secretary (and member of the ANC National Executive Committee), Minister of Higher and Professional Education deserves attention: "The fact of the matter is that the relationship between the Guptas and our movement and the government it leads is TOXIC! But at the same time we need to point out that blaming the Guptas alone is not enough. The question that has to be answered is who is this family working with on the side of our movement and government?" 65

The SACP Political Bureau called the ANC leadership "to reflect critically on the capacities and motives of a circle of informal presidential courtiers, flatterers, patrons, factionalists and hangers-on. It is a circle that, in our view, continuously and prejudicially exposes the presidency" 66

Under these circumstances the election held on 3 August, though

62 http://www.anc.org.za/docs/umrabulo/20I5/ngc_disc_docsy.pdf

63 http://www.theguardian.com/us-news/2016/may/i5/cia-operative-nelson-mandelaig62-arrest

64 http://www.bdlive.co.za/national/politics/20I6/05/22/pravin-gordhan-urges-unity-andreturn-to-old-values-in-anc

${ }_{5}$ http://politicsweb.co.za/news-and-analysis/blaming-the-guptas-alone-is-not-enough-blade-nzim

66 http://www.sacp.org.za/main.php?ID=5240\#sthash.6y9yVvUf.dpuf 
local, acquired national importance. The discussions the author had in South Africa prior to it showed that there were two "schools of thought" in the ANC: some believed that Zuma became an "albatross around the neck" of the party, while others thought that his resignation on the eve of the election would cause chaos and damage the party's position.

The latter point of view prevailed, but the election results inevitably brought back the controversial issue. Initially the ANC leadership put a "brave face", emphasizing in their statement the fact that the party received more votes "than ever before" ${ }^{67}$. However in reality those millions constitute just $54.5 \%$ of votes cast, that is almost $8 \%$ less than in 20II. "On the surface" it was still not bad; twice more than the DA which result was better by $3 \%$, while the results of the EEF was much lower than their ambitions, instead of doubling or even tripling the number of words, the rise was just about $2 \%$. However the ruling party suffered a serious setback in all major municipalities except eThekwini (Durban). The DA strengthened its grip on Cape Town, won a relative majority in municipalities of Tshwane, the administrative capital, and of Nelson Mandela Bay (Port-Elizabeth) and reduced ANC majority to relative in Johannesburg and Erkhuhuleni. So, as South African press put it, "the era of coalitions" has come ${ }^{68}$, and in spite of its third place, the EFF received a chance to become a "kingmaker" ${ }^{9}$ in several cases.

Its "radical" leadership used a rather canny tactics. "To safe a face" it held talks with the ANC, but put eight unacceptable conditions, including the "removal" of Zuma, and after the talks failed made a deal with the "rightwing" DA. However Malema emphasized that his party would not form coalition but would support DA "in hung metros"70. So with assistance of the EEF and some small parties the DA managed to get control not only of Tshwane and Nelson Mandela Bay, but of Johannesburg as well, though the ANC received there more votes than its main opponent.

Many prominent members and rank and file put the blame for the ANC letdown on its leader whose image has been marred by the scandals. However according to ANC Secretary General Gwede Mantashe, though the members of the party's National Executive Committee spent several days discussing the debacle "There was no proposal [at the NEC] meeting that

67 http://www.anc.org.za/content/many-more-vote-anc-2oi6-ever 68 http://www.citizen.co.za/r2378ro/welcome-to-the-era-of-coalition-politics-2/

69 Term used to illustrate a situation where a player through his actions in the game determines the winner of the game (other than himself).

$70 \mathrm{mg} . c 0 . z a / a r t i c l e / 20 \mathrm{I} / 08$-I7-malema-says-the eff-wont-form-coalition-but-will-supportda-in-hung-metros 
the president step down"ᄁ. But more and more voices are calling for earlier holding of the ANC national "elective" conference.

ANC chief whip Jackson Mthembu appropriately stated in parliament that the losses suffered by the ANC "were self-imposed" and "not because any other party is better". All in all the ANC had won over $78 \%$ of the wards in the country, but lost "key metros" that are "critical to the economy of the country as they control serious budgets".

Besides, the moral blow to the ANC is hard to overestimate. Zuma used to say that people needed to accept that the ANC would rule "until Jesus Christ comes back"72 and this phrase boomeranged. After the election a bad joke became popular: "Zuma might have gone to OR Tambo International airport to welcome Jesus. ${ }^{73}$

However, the responsibility for election debacle should not lie on one man. COSATU President Sidumo Dlamini stated, "We must demonstrate that we have listened to that final warning shot which seems to be saying stop factionalism in the movement while the working class is under siege. They [voters] expected that the ANC could do good to the promise of a socioeconomic and radical phase in our democracy to transform lives"74. Indeed, the main issue in South Africa is deeper than actions (or lack of them) of one politician, as important as he happens to be, or of his "circle". It may be rather reduced to a question: can the plight of the majority be greatly improved without undertaking radical social and economic actions?

Nevertheless, though South Africa is facing nowadays all sorts of problems caused by both internal and external reasons, yet each time you visit it ${ }^{75}$ you cannot but see a contrast between the actual situation (as difficult as it may be) and the picture being drawn in the so-called international media, where, according to Nzimande, "South Africa has consistently portrayed always five minutes to midnight, always on the verge of collapse and transformation into a "failed state" ${ }^{76}$. In refutation of this just one argument. Often, in the media and in futile conversations one can see and hear complains about the "expulsion" of whites from South Africa. In reality, the situation there is, rather the opposite: in five years, 359.000

7I http://www.polity.org.za/article/coalition-talks-enter-critical-stage-20ı6-o8-ı5 72 http://mg.co.za/article/20I6-07-05-zuma-repeats-that-anc-will-rule-until-jesus-comes 73 http://www.citizen.co.za/ı240868/where-is-zuma-maybe-hes-with-jesus/ 74 http://www.iol.co.za/news/politics/voters-have-fired-their-final-warning-shotcosatu-2056476

75 Author's latest visits were in April and August 2016.

76 http://www.sacp.org.za/main.php?ID=4810 
immigrants, that is about $40 \%$ returned home 7 . And this fact alone allows South Africans and their friends, despite all the difficulties, to look with optimism to the future.

\section{ABSTRACT}

South Africa is currently facing several political dilemmas that influence the entire social organization of the country. Thus, the historicity of the political processes that permeate South African society today, the power plays of the country's elites, as well as the external influences that act internally through the political parties of South Africa, and the presence of important African nation within the scope of the BRICS, are essential elements for understanding the South African policy context. Through of experiences in loco, this article establishes a comprehensive analysis of the situation, not only pointing out the political agents which actively intervene in this game, but also constructing possible scenarios for the unfolding of the events.

\section{KEYWORDS}

South Africa; political process; ANC; Jacob Zuma.

Received on June 20, 2016 Approved on September 28, 2016.

77 http://homecomingrevolution.com/south-africa/ 